\title{
ANALISIS PENGARUH FRAUD DIAMOND DAN GOOD CORPORATE GOVERNANCE DALAM MENDETEKSI KEMUNGKINAN TERJADINYA FRAUDULENT FINANCIAL STATEMENT
}

\author{
Nila Chandra \\ Institut Bisnis dan Informatika Kwik Kian Gie \\ cu77ie.nla@gmail.com \\ Sugi Suhartono \\ Institut Bisnis dan Informatika Kwik Kian Gie \\ sugi.suhartono@kwikkiangie.ac.id
}

\begin{abstract}
In the financial statements there is a possibility of misstatements in the presentation of company's financial statements relating to errors or fraud made or caused by managers in the company. Misrepresentation in financial statements causes a decrease in the level of trust of users of financial statements and can harm stakeholders. The theories underlying this research include agency theory, fraud diamond, and good corporate governance. The research sample consisted of 46 manufacturing companies listed on the Stock Exchange in the period 2015-2017. Sampling is done by purposive sampling method. Hypothesis testing uses analysis of descriptive statistics, pooling test, independent sample t-test and logistic regression analysis. The results of this study indicate that financial stability, nature of industry, rationalization, and capability have a positive effect on the possibility of fraudulent financial statements. Whereas female on board has a negative effect on the possibility of fraudulent financial statements. But external pressure, personal financial need, effective monitoring and independent board of commissioners are not proven to have effect on the possibility of fraudulent financial statements.
\end{abstract}

Keywords: Fraudulent Financial Statement, Fraud Diamond, Good Corporate Governance

\section{PENDAHULUAN}

Entitas dalam sebuah penyajian laporan keuangan adalah aset, liabilitas, ekuitas, arus kas, penghasilan, dan beban yang dapat dijadikan sebagai alat pengambilan keputusan. Statement of Financial Accounting Concept (SFAC) No. 1 memaparkan bahwa unsur utama dalam menilai suatu kinerja atau pertanggungjawaban manajemen adalah dilihat dari informasi laba. Oleh karena itu, laporan keuangan yang dibuat oleh perusahaan harus bermutu dan terpercaya untuk mengambil keputusan investasi. Terkadang hasil kinerja yang tertuang dalam laporan keuangan lebih bertujuan untuk mendapatkan kesan 
"baik" dari berbagai pihak. Dorongan atau motivasi untuk selalu terlihat baik oleh berbagai pihak sering memaksa perusahaan untuk melakukan manipulasi di bagian-bagian tertentu, sehingga pada akhirnya menyajikan informasi yang tidak semestinya dan tentunya akan merugikan banyak pihak. Selain itu, tidak menutup kemungkinan adanya salah saji dalam penyajian laporan keuangan perusahaan yang dikarenakan dari kekeliruan atau kecurangan atas perlakuan manajer. Salah saji dalam laporan keuangan memiliki dampak yang menyebabkan berkurangnya tingkat kepercayaan pengguna laporan keuangan dan dapat merugikan para pemangku kepentingan seperti pemberi pinjaman, pemasok, karyawan, pelanggan, investor, masyarakat, dan pemerintah. Oleh karena itu kecurangan pelaporan keuangan menjadi isu yang penting karena telah menyebabkan kerugian finansial dan non finansial seperti permasalahan sistem keuangan dan kebangkrutan. Kecurangan dan pelanggaran yang terjadi di dalam perusahaan merupakan ancaman terhadap kepercayaan publik dalam membangun kepercayaan dari pasar modal. Peningkatan insiden kecurangan mengindikasikan bahwa ada kebutuhan yang kuat untuk penelitian yang bertujuan untuk mengidentifikasi metode yang efektif untuk mendeteksi potensi kecurangan. Konsep kecurangan digunakan untuk mendeteksi penyebab kecurangan yang pertama kali dikembangkan oleh Cressey (1953) dalam Indarto dan Ghozali (2016) yang dinamakan fraud triangle yang terdiri dari 3 (tiga) komponen yaitu tekanan (pressure), kesempatan (opportunity), dan rasionalisasi (rationalization). Dalam perkembangannya, Wolfe dan Hermanson (2004) menyatakan masih terdapat satu faktor tambahan dalam teori fraud triangle tersebut, yaitu capability (kemampuan), sehingga dinamakan fraud diamond theory. Kecurangan juga tidak akan terjadi jika tata kelola perusahaan diterapkan dengan benar sehingga dapat digunakan untuk mengatur dan mengendalikan perusahaan untuk menciptakan nilai tambah bagi semua pemangku kepentingan. Tata kelola perusahaan diarahkan untuk mengurangi asimetri informasi antara prinsipal dan agen, yang pada gilirannya dapat mengurangi tindakan kecurangan. Tujuan Penelitian adalah untuk mengetahui pengaruh financial stability, external pressure, 
Analisis Pengaruh Fraud Diamond dan Good Corporate Governance Dalam Mendeteksi Kemungkinan

Terjadinya Fraudulent Financial Statement

personal financial need ; nature of industry; effective monitoring, rationalization; capability, dewan komisaris, dan female on board dalam

\section{TELAAH LITERATUR}

Teori Agensi (Agency Theory)

Teori agensi (agency theory) adalah teori yang terjadi karena adanya konflik antara kepentingan pihak principal dengan kepentingan pihak agent. Teori agensi mendeskripsikan hubungan antara pemegang saham sebagai principal dengan manajemen sebagai agent. Jensen dan Meckling (1976) mengatakan adanya kontrak satu atau lebih pihak yang menggunakan pihak lain melakukan sesuatu bagi kepentingan mereka berdasarkan wewenang untuk mengambil keputusan ke pihak lain tersebut disebut sebagai hubungan agensi. Bila kedua belah pihak yang terlibat dalam hubungan tersebut adalah pihak yang berusaha untuk memaksimalkan utilitasnya masing-masing, maka akan timbul kemungkinan dimana pihak agent tidak selalu bertindak demi kepentingan principal. Pihak agent sering kali termotivasi untuk memaksimalkan bonus yang diterimanya. Hal tersebut berlawanan dengan kepentingan pihak pendeteksian terhadap kemungkinan terjadinya fraudulent financial statement.

principal yang berusaha untuk memaksimalkan pengembalian atas sumber dayanya, sehingga dapat menimbulkan konflik kepentingan antara pihak agent dan principal. Dengan adanya konflik kepentingan tersebut menimbulkan berbagai tekanan bagi perusahaan, dimana perusahaan harus meningkatkan kinerjanya agar dapat memberikan rasionalisasi. Kemungkinan kecurangan juga dapat dengan mudah terjadi ketika manajemen memiliki kemampuan, akses dan posisi yang kuat dan strategis (capability) dan juga peluang untuk melakukan kecurangan akuntansi (opportunities). Berdasarkan asumsi sifat dasar manusia, manajer sebagai manusia kemungkinan besar akan bertindak berdasarkan sifat opportunistic. Maksud dari sifat opportunistic adalah bahwa manajer akan lebih mengutamakan kepentingan pribadinya dibandingkan kepentingan orang lain (pemegang saham). Agen akan berusaha mencari keuntungannya sendiri untuk mendapatkan bonus dari 
perusahaan dengan berbagai cara seperti memanipulasi angka - angka di laporan keuangan. Hubungan teori ini dengan penelitian adalah perilaku manajemen laba dapat dipandang sebagai perilaku opportunis ataupun efektif (Santoso, 2015). Ketika manajemen laba dilakukan untuk mengurangi konflik ketegangan, manajemen laba yang dilakukan dapat dikatakan sebagai efektif. Apabila manajemen (agen) melakukan manajemen laba untuk mencapai kepentingannya sendiri, perilaku ini dikatakan sebagai perilaku opportunis. Manajemen sebagai agent biasanya melakukan kecurangan laporan keuangan untuk kepentingannya sendiri yang akan menghasilkan konflik dengan pemegang saham selaku principle. Perbuatan ini dilakukan manajemen dengan memanfaatkan kelemahan pihak lain yang tidak mempunyai sumber dan akses yang memadai untuk memperoleh informasi mengenai perusahaan. Tujuan opportunis mungkin dapat merugikan pemakai laporan keuangan karena informasi yang disampaikan manajemen menjadi tidak akurat dan juga tidak menggambarkan nilai fundamental perusahaan. Sikap opportunis ini dinilai sebagai sikap curang manajemen yang diimplikasikan dalam laporan keuangan.

Fraud

Fraud adalah suatu perbuatan yang melawan hukum, mengandung unsur kesengajaan, niat jahat, penipuan, penyembuyian, dan penyalahgunaan kepercayaan serta perbuatan tersebut bertujuan mengambil keuntungan haram (illegal advantage) yang bisa berupa uang, barang/harta, dan jasa (Priantara, 2013:4-5). Dalam SAS No. 99 menyatakan bahwa fraudulent financial statement adalah kesengajaan dalam menghasilkan salah saji material dalam laporan keuangan yang merupakan subjek audit. Dalam "Financial Accounting IFRS Edition" menurut Weygandt, Kimmel, dan Kieso (2015) menyatakan, "Fraud is a dishonest act by an employee that result in personal benefit to the employee at a cost to employer."

\section{Fraud Triangle}

Tiffani dan Marfuah (2015) menyatakan bahwa fraud triangle theory merupakan suatu gagasan tentang penyebab terjadinya kecurangan yang dikemukakan oleh Cressey (1953) yang dinamakan fraud triangle. Fraud triangle menjelaskan tiga faktor yang 
Analisis Pengaruh Fraud Diamond dan Good Corporate Governance Dalam Mendeteksi Kemungkinan

Terjadinya Fraudulent Financial Statement

hadir dalam setiap situasi fraud, yaitu pressure, opportunity dan rationalization.

\section{Fraud Diamond}

Wolfe dan Hermanson (2004) berpendapat bahwa, meskipun tekanan atau insentif yang dirasakan mungkin ada bersama dengan peluang dan rasionalisasi untuk melakukan kecurangan, kecurangan tidak mungkin terjadi kecuali elemen keempat hadir, yaitu: capability. Dengan kata lain, pelaku potensial harus memiliki keterampilan dan kemampuan untuk benar-benar melakukan kecurangan.

\section{Metode Deteksi Kecurangan}

Beneish M-Score model merupakan model probabilistik sehingga tidak dapat mendeteksi fraud dengan ketepatan 100\%. Tetapi dapat menentukan $76 \%$ manipulators secara akurat, dan $17.5 \%$ non-manipulators secara tidak akurat. rumus Beneish $M$ Score Model yaitu:

Beneish M-Score $=-4.84+0.920$ DSRI $+0.528 \mathrm{GMI}+0.404 \mathrm{AQI}+0.892 \mathrm{SGI}$

+0.115 DEPI - 0.172 SGAI - 0.327 LVGI + 4.679 TATA
Angka -4.84 merupakan konstanta dan delapan variabel rasio keuangan dikalikan dengan masing-masing konstanta. Jika Benesih M-Score lebih besar dari -2.22, dikategorikan sebagai perusahaan yang melakukan fraud. Sedangkan jika skor lebih kecil dari 2.22, dikategorikan sebagai perusahaan yang tidak melakukan fraud (nonfraud). Selanjutnya perusahaan yang melakukan fraud diberi skor 1 dan yang tidak melakukan fraud (non-fraud) diberi skor 0 .

\section{Good Corporate Governance}

Meningkatnya insiden kecurangan di dalam perusahaan menunjukkan bahwa terdapat penekanan yang tidak efektif pada pencegahan kecurangan dan mekanisme pencegahan. Dalam banyak kasus kecurangan yang baru-baru terjadi, kegagalan struktur tata kelola perusahaan sebagai alat pemantauan yang efektif telah menjadi salah satu alasan untuk mencegah pelaporan keuangan yang curang. Ini menyimpulkan bahwa struktur tata kelola perusahaan yang efektif memiliki dampak positif dalam mengurangi insiden tersebut. 
Pengaruh Financial Stability terhadap Kemungkinan Terjadinya Fraudulent Financial Statement

Financial Stability adalah situasi yang menggambarkan suatu kondisi keuangan perusahaan yang berada dalam keadaan yang stabil dan tidak bergejolak atau berfluktuasi terlalu ekstrim. Manajer menghadapi tekanan untuk melakukan financial statement fraud ketika stabilitas keuangan dan profitibilitas terancam oleh keadaan ekonomi, industri, dan situasi entitas yang beroperasi (Skousen, Smith, dan Wright, 2008). Penelitian Loebbecke et al., (1989) dan Bell et al., (1991) dalam (Skousen, Smith, dan Wright, 2008) menyatakan perusahaan dalam mengikuti periode pertumbuhan yang cepat, manajemen dapat menggunakan manipulasi laporan keuangan untuk menyediakan penampilan pertumbuhan yang stabil. Oleh karena itu peneliti menggunakan pertumbuhan aset (growth in asset) sebagai proksi untuk financial stability (Beneish, 1997); (Beasley et al., 2000). Aset perusahaan dapat digunakan untuk melihat kondisi keuangan perusahaan, karena aset dapat menggambarkan kekayaan yang dimiliki oleh perusahaan. Kondisi keuangan yang stabil dapat memperkecil risiko terjadinya kecurangan laporan keuangan. Kondisi tersebut dapat dilihat dari perubahan aset yang tidak terlalu signifikan berbeda dari tahun sebelumnya. Hal ini dapat menjadi tekanan bagi manajer untuk menampilkan kondisi perubahan aset yang stabil dan menunjukkan stabilitas perusahaan yang terlihat baik kepada para pengguna laporan keuangan, sebagai upaya menarik minat investor untuk menanamkan modal diperusahaannya, dan memaksimalkan kinerjanya dimata para pemilik perusahaan. Penelitian Annisya dkk., (2016) dan Husmawati et al., (2017) menyatakan bahwa financial stability berpengaruh positif signifikan terhadap fraudulent financial statement, yang menunjukkan semakin tinggi rasio perubahan total aset suatu perusahaan, semakin tinggi juga tingkat risiko kecurangan pada laporan keuangannya. Karena pertumbuhan aset yang berlebihan juga tidak baik bagi perusahaan. Tentunya, jika aset mengalami pertumbuhan tinggi, maka manajemen cenderung akan memanipulasi laporan keuangan untuk menjaga kondisi keuangan perusahaan yang stabil. 
Ha_1: Financial stability berpengaruh positif terhadap kemungkinan terjadinya fraudulent financial statement.

Pengaruh External Pressure terhadap Kemungkinan Terjadinya Fraudulent Financial Statement.

External pressure adalah kemampuan untuk memenuhi persyaratan daftar bursa, membayar utang atau memenuhi perjanjian utang merupakan sumber tekanan eksternal yang diakui secara luas. Manajer dapat merasakan tekanan sebagai akibat dari kebutuhan untuk mendapatkan tambahan utang atau ekuitas pembiayaan agar tetap kompetitif. Contohnya, keuangan mungkin diperlukan untuk melakukan penelitian dan pengembangan utama atau untuk memperluas pabrik dan fasilitas (Skousen, Smith, dan Wright, 2008). Tak dipungkiri bahwa perusahaan tidak bisa terlepas dari hutang. Hutang tersebut digunakan perusahaan untuk melakukan suatu ekspansi yang dapat mempengaruhi kinerja perusahaan secara signifikan. Perusahaan untuk memenuhi perjanjian dan pembayaran utang secara umum dapat dianalisis melalui rasio solvabilitas atau leverage di mana rasio ini akan membandingkan jumlah dana yang disediakan oleh peminjam dengan jumlah dana yang dipinjam dari pemberi pinjaman. Untuk mendapatkan pinjaman dari pihak eksternal, perusahaan harus diyakini mampu untuk mengembalikan pinjaman yang telah diperolehnya. Apabila perusahaan memiliki leverage yang cukup tinggi, berarti perusahaan itu memiliki hutang yang besar dan risiko kredit yang dimiliki juga tinggi. Karena memiliki risiko kredit yang tinggi, maka terdapat kekhawatiran bahwa pada nantinya perusahaan tidak mampu untuk mengembalikan pinjaman modal yang diberikan sehingga menimbulkan keraguan dalam diri pemberi pinjaman untuk meminjamkan modalnya. Oleh karena itu, perusahaan harus menyelamatkan diri dari kondisi yang demikian agar tetap dianggap mampu untuk mengembalikan pinjaman. Penelitian Harto (2016) menyatakan bahwa semakin tinggi leverage maka akan terjadi kemungkinan yang lebih besar untuk melakukan pelanggaran terhadap perjanjian kredit melalui kecurangan pelaporan keuangan. Penelitian Razali dan Arshad (2014), Zaki (2017) dan Indarto dan Ghozali (2016) juga menyatakan bahwa external 
pressure berpengaruh positif signifikan terhadap fraudulent financial statement.

Ha_2 : External pressure berpengaruh positif terhadap kemungkinan terjadinya fraudulent financial statement.

Pengaruh Personal Financial Need terhadap Kemungkinan Terjadinya Fraudulent Financial Statement.

Beasley (1996), COSO (1999), dan Dunn (2004) menunjukkan bahwa ketika eksekutif memiliki kepemilikan saham yang signifikan dalam perusahaan, keuangan perusahaan ikut terpengaruh oleh kondisi keuangan para pengambil keputusan (eksekutif). Penelitian Utomo (2018) menyatakan bahwa kepemilikan saham yang tinggi mengidentifikasikan bahwa pada perusahaan telah terjadi pemisahan yang tidak jelas antara pemegang saham sebagai pemilik yang mengontrol jalannya perusahaan dan manajer sebagai pengelola perusahaan. Dalam penelitian Tiffani dan Marfuah (2015), menyatakan bahwa kepemilikan saham oleh manajemen dalam perusahaan menimbulkan adanya prasangka oleh dirinya atas hak penghasilan dan aktiva perusahaan sehingga akan mempengaruhi kondisi keuangan perusahaan. Ketidakjelasan pemisahan antara fungsi pengelolaan dan pengendalian dari perusahaan dapat menimbulkan para eksekutif sewenangwenang dalam menggunakan dana perusahaan untuk kepentingan mereka. Contoh, kepentingan pribadi yang menjadi tekanan yang nantinya dialami oleh manajer akan memicu terjadinya kecurangan laporan keuangan antara lain tekanan keuangan, tekanan kebiasaan buruk, dan tekanan berkaitan dengan pekerjaan. Semakin tinggi jumlah kepemilikan saham oleh manajer dalam perusahaan maka akan mendorong praktik kecurangan dalam memanipulasi laporan keuangan semakin tinggi. Penelitian Utomo (2018) didukung oleh penelitian Nugraheni dan Triatmoko (2016) yang menyatakan bahwa personal financial need berpengaruh positif signifikan terhadap fraudulent financial statement.

Ha_3: Financial personal need berpengaruh positif terhadap kemungkinan terjadinya fraudulent financial statement.

Pengaruh Nature of Industry terhadap Kemungkinan Terjadinya Fraudulent Financial Statement. 
Konflik kepentingan dalam teori agensi dapat menimbulkan motivasi bagi manajemen untuk melakukan manipulasi agar terlihat baik hasil kerjanya dimata investor, sehingga tujuan tercapai. Namun manipulasi ini akan sulit terjadi ketika tidak terdapat peluang atau celah untuk melakukan manipulasi tersebut. Standar akuntansi mengizinkan perusahaan untuk menyusun laporan keuangan secara fleksibel menyesuaikan keadaan dan kondisi yang dihadapi. Hal ini merupakan kondisi yang normal dan biasa terjadi di dalam kehidupan seharihari atau lebih dikenal dengan karakteristik industri pada umumnya. Oleh karena diperkenankan oleh standar, maka terbuka peluang bagi manajemen untuk dapat memanipulasi saldo akun-akun yang terdapat dalam laporan keuangan. Dalam suatu laporan keuangan terdapat saldo akun yang dinyatakan dengan penilaian subjektif. Besar kecilnya saldo akun ini ditentukan oleh perkiraan dan penilaian subjektif dari manajemen sehingga dapat menjadi peluang untuk melakukan manipulasi. Manajemen dapat merumuskan cadangan piutang tidak tertagih dengan menggunakan perkiraan (judgement) dan penilaian mereka sehingga saldo akun piutang dalam laporan keuangan mengikuti kemauan manajemen. Argumen tersebut didukung oleh Summers dan Sweeney (1998) yang menyatakan bahwa perkiraan akun yang ditentukan secara subyektif adalah akun yang tidak dapat ditagih dan obsolete inventory. Mereka menyarankan bahwa manajemen dapat fokus pada akun tersebut saat terlibat dalam manipulasi laporan keuangan. Karena manajer dapat menggunakan akun tersebut sebagai alat untuk manipulasi laporan keuangan. Secara konsisten, Loebbecke et al., (1989) juga mengamati bahwa sejumlah kecurangan dalam sampel mereka melibatkan piutang dan persediaan. Penelitian Putriasih dkk., (2016) mengatakan bahwa perusahaan yang baik akan berusaha untuk memperkecil jumlah piutang dan memperbanyak penerimaan kas perusahaan. Penelitian Putriasih dkk., (2016) didukung oleh penelitian Prayatna dan Fitriany (2014) yang menyatakan bahwa nature of industry berpengaruh positif signifikan terhadap fraudulent financial statement.

Ha_4 : Nature of Industry berpengaruh positif terhadap kemungkinan terjadinya fraudulent financial statement. 
Pengaruh Effective Monitoring terhadap Kemungkinan Terjadinya Fraudulent Financial Statement.

Teori agensi muncul ketika prinsipal mempekerjakan atau mendelegasikan tugas kepada agen dalam suatu kontrak. Teori agensi ini kemudian mampu menimbulkan permasalahan diantara prinsipal dan agen karena ada ketidakseimbangan informasi yang dimiliki kedua pihak tersebut atau lebih dikenal dengan istilah asimetri informasi antara prinsipal dan agen. Ketidakseimbangan informasi ini menguntungkan pihak agen yang selalu berada hampir setiap saat di dalam perusahaan sehingga mereka mengetahui informasi perusahaan yang cukup lengkap. Karena kurangnya informasi yang didapat oleh prinsipal inilah yang kemudian dimanfaatkan agen untuk melakukan kecurangan terutama ketika kondisi perusahaan tidak baik dimata agen. Tindakan kecurangan tersebut dapat diminimalkan dengan melakukan pengawasan yang baik. Meluasnya skandal dan tindakan kecurangan dalam dunia akuntansi merupakan salah satu akibat lemahnya pengawasan atau kurang efektifnya pengawasan yang dilakukan oleh perusahaan yang telah memberikan peluang kepada agen untuk bertindak sesuai dengan kepentingannya. Komite audit dipercaya dapat meningkatkan efektivitas pengawasan perusahaan. Penelitian Abbott dan Parker (2000); Abbott et al., (2000); Beasley et al., (2000); Robinson (2002) dalam Skousen et al., (2008) mengidentifikasikan hubungan antara anggota komite audit independen dengan insiden kecurangan. Komite audit merupakan suatu komponen yang memiliki peran yang sangat vital sebagai sistem pengendalian perusahaan. Semakin besar proporsi komite audit independen, maka proses monitoring terhadap perusahaan semakin efektif sehingga akan menurunkan potensi manajemen untuk melakukan kecurangan laporan keuangan. Selain itu, Beasley et al., (2000) mengamati penurunan insiden kecurangan di antara perusahaan yang memiliki komite audit. Komite audit yang lebih besar dikaitkan dengan insiden kecurangan yang lebih rendah Beasley et al., (2000). Prayatna dan Fitriany (2014) menyatakan jika tidak ada komisaris di komite audit yang ahli di bidang keuangan atau akuntansi, pengendalian internal akan melemah, 
dengan itu manajer akan memiliki peluang lebih besar untuk memanipulasi laporan keuangan. yang mengakibatkan probabilitas perusahaan mendapatkan sanksi yang lebih berat dari OJK akan meningkat. Penelitian Utomo (2018) sejalan dengan penelitian Prayatna dan Fitriany (2014) yang menyatakan bahwa effective monitoring berpengaruh negatif terhadap fraudulent financial statement. Hal ini menunjukkan perusahaan yang memiliki tingkat efektifitas pengawasan rendah yang akan menaikan potensi manajemen untuk melakukan kecurangan laporan keuangan. Dan juga penelitian Razali dan Arshad (2014) menyatakan bahwa komite audit independen.

Ha_5: Effective Monitoring berpengaruh negatif terhadap kemungkinan terjadinya fraudulent financial statement.

Pengaruh Rationalization terhadap Kemungkinan Terjadinya Fraudulent Financial Statement.

Rationalization merupakan sebuah pandangan bahwa pada dasarnya orang itu dapat dipercaya. Kalaupun yang bersangkutan berbuat kecurangan atau fraud, hal tersebut tidak membuat yang bersangkutan menganggap dirinya sebagai fraudster sehingga apabila tertangkap karena kecurangannya, mereka menganggap bahwa mereka adalah korban dari sistem atau lingkungan yang tidak baik atau lingkungan yang menganggap perbuatan fraud adalah biasa. Independensi auditor eksternal adalah alat pemantauan penting untuk menjamin kualitas pelaporan keuangan. Hubungan manajemen-auditor sangat penting dalam menentukan rasionalisasi di perusahaan. Ketika manajemen tidak memiliki hubungan yang baik dengan auditor, perusahaan lebih mungkin menghadapi kecurangan. Insiden kegagalan audit dan litigasi meningkat setelah perubahan auditor (Stice, 1991); (St. Pierre dan Anderson, 1984); (Loebbecke et al., 1989). Sorenson et al., (1983) dalam Ghafoor et al., (2018) berpendapat bahwa manajemen dapat mengubah auditor untuk mengurangi deteksi kecurangan. Hal ini didokumentasikan oleh Loebbecke dan Willingam (1988) dalam Ghafoor et al., (2018), yang menemukan bahwa hampir $36 \%$ dari sampel mereka memiliki tuduhan penipuan dalam dua tahun pertama perubahan auditor. Selanjutnya, Shu (2000) menemukan 
hubungan positif antara pengunduran diri auditor dan probabilitas litigasi. Penelitian Siddiq dkk., (2017) menyatakan bahwa change in auditor dalam suatu perusahaan merupakan bentuk dari upaya dalam menghilangkan jejak fraud (fraud trail) yang terdeteksi oleh auditor sebelumnya. Penelitian Putriasih dkk., (2016), Pamungkas dkk., (2018), dan Ghafoor et al., (2018) sejalan dengan penelitian Siddiq dkk., (2017) yang menyatakan bahwa change in auditor berpengaruh positif signifikan terhadap fraudulent financial statement.

Ha_6 : Rationalization berpengaruh terhadap kemungkinan terjadinya fraudulent financial statement.

Pengaruh Capability terhadap Kemungkinan Terjadinya Fraudulent Financial Statement.

Sebagai perpanjangan dari model fraud triangle, beberapa penelitian menambahkan faktor keempat untuk tiga faktor dalam model fraud triangle, yaitu kemampuan (capability), ini mengacu pada keterampilan dan karakteristik individu, yang memungkinkan mereka untuk melakukan kecurangan. Karena kecurangan tidak akan terjadi jika tidak dilakukan oleh seseorang dengan kemampuan yang tepat dan posisi yang tepat untuk melaksanakan setiap detail kecurangan. Wolfe dan Hermanson (2004) juga menjelaskan bahwa posisi, kebohongan yang efektif, kekebalan terhadap stres, otak, ego, dan keterampilan memaksa adalah elemen dari kemampuan. Posisi CEO, direktur, dan kepala divisi lain cenderung paling sesuai dengan karakteristik tersebut. Posisi itu dapat menjadi penentu dalam tindakan kecurangan dengan menggunakan posisi mereka untuk mempengaruhi orang lain untuk mempercepat dan membantu tindakan kecurangan mereka. Kemampuan berarti upaya seseorang dalam melakukan kecurangan untuk mencapai tujuan tertentu, yang dikenal sebagai model fraud diamond. Capability yaitu elemen yang ditambahkan dalam penelitian Wolfe dan Hermanson (2004) untuk meningkatkan kemampuan mendeteksi dan mencegah kecurangan. Wolfe dan Hermanson (2004) percaya bahwa meskipun fraudster mungkin memiliki tekanan, kesempatan untuk melakukan penipuan dan merasionalisasi ideologi mengkhianati kepercayaan. Namun, dia tidak bisa 
menyembunyikan kecuali dia memiliki kemampuan untuk melakukannya. Hal ini sejalan dengan teori agensi yang menekankan pentingnya pemilik perusahaan (pemegang saham) untuk menyerahkan pengelolaan perusahaan kepada tenaga-tenaga profesional. Teori ini menjelaskan bahwa kunci untuk mengurangi kecurangan adalah fokus pada situasi tertentu yang terjadi di samping tekanan dan rasionalisasi dan juga kombinasi dari peluang dan kemampuan. Wolfe dan Hermanson (2004) menyatakan bahwa perubahan direksi akan dapat menyebabkan stress period yang berdampak pada semakin terbukanya peluang untuk melakukan fraud. Penelitian Putriasih dkk., (2016) dan Pamungkas et al., (2018) sejalan dengan penelitian Wolfe dan Hermanson (2004) yang menyatakan bahwa pergantian direksi berpengaruh positif terhadap fraudulent financial statement.

Ha_7: Capability berpengaruh terhadap kemungkinan terjadinya fraudulent financial statement.

Pengaruh Dewan Komisaris Independen terhadap Kemungkinan Terjadinya Fraudulent Financial Statement.

Dewan komisaris memiliki wewenangan dan tanggung jawab penuh dalam mengendalikan, mengawasi dan mengarahkan pengelolaan sumber daya perusahaan (Syakhroza, 2005) dalam (Pamungkas et al., 2018). Ketika sebuah perusahaan memiliki dewan komisaris yang bekerja secara efektif maka kinerja perusahaan juga akan baik. Kualitas fungsi ini merupakan penentu efektivitas tata kelola perusahaan. Perbedaan kepentingan antara pemilik perusahaan dan manajemen dapat diselaraskan dengan mekanisme tata kelola perusahaan. Pemantauan yang dilakukan oleh dewan komisaris dan pemegang saham merupakan mekanisme penting dalam menyelaraskan kepentingan pemegang saham dan manajemen. Efektivitas pemantauan perusahaan yang dilakukan oleh dewan komisaris independen akan meminimalkan kecurangan. Penelitian Oktarigusta (2015) dan Abdillah dan Susilawati (2014) menyatakan bahwa komisaris independen berpengaruh negatif terhadap kecurangan laporan keuangan. Dikarenakan semakin banyak anggota komisaris independen maka proses pengawasan yang dilakukan dewan ini semakin berkualitas karena semakin banyaknya pihak independen 
yang menuntut adanya transparansi dalam pelaporan keuangan perusahaan.

Ha_(8 ): Dewan komisaris independen berpengaruh negatif terhadap kemungkinan terjadinya fraudulent financial statement.

Pengaruh Female on Board terhadap Kemungkinan Terjadinya Fraudulent

\section{Financial Statement.}

Satu bentuk keragaman berasal dari gaya kepemimpinan wanita yang berbeda. Teori peran sosial kepemimpinan Eagly dan Johnson (1990) dan Eagly et al., (1995) menguraikan bahwa pemimpin perempuan cenderung lebih menunjukkan kepedulian terhadap orang dan mencari kesejahteraan (persekutuan), sementara pemimpin laki-laki cenderung lebih memiliki sifat (agen) yang memperkuat persaingan dan hierarki. Serupa dengan itu, sering dilaporkan dalam praktik bahwa perempuan adalah pendengar yang lebih baik dan mencari pendengar yang lebih baik, terutama dalam kaitannya dengan masalah keuangan. Kita mungkin berharap bahwa kepekaan, perhatian moralitas, dan perbedaan risiko antara perempuan dan laki-laki harus tercermin dalam kepatuhan mereka dengan peraturan perusahaan. Dalam konteks bisnis, wanita lebih etis di tempat kerja dan cenderung jarang terlibat dalam perilaku yang tidak etis untuk mendapatkan imbalan keuangan (Betz et al., 1989). Penelitian Gul et al., (2009) berpendapat bahwa perempuan tidak hanya menunjukkan penghindaran risiko dan perilaku etis yang lebih besar, tetapi mereka juga lebih baik dalam memperoleh informasi sukarela yang dapat mengurangi asimetri informasi antara direktur perempuan dan manajer. Perempuan lebih berhati-hati dan kurang agresif daripada laki-laki dalam berbagai konteks pengambilan keputusan Byrnes et al., (1999), dan cenderung kurang mengambil risiko terutama dalam lingkungan keputusan keuangan (Powell dan Ansic, 1997). Oleh karena itu manajemen laba akan lebih terkendali. Penelitian Capezio dan Mavisakalyan (2016) dan Ghafoor et al., (2018) menyatakan bahwa representasi female on board memiliki dampak negatif dan signifikan secara statistik terhadap kemungkinan kecurangan. Memiliki representasi female on board yang lebih besar dapat mengurangi kemungkinan kecurangan 
dan meningkatkan kinerja keuangan perusahaan.

Ha_9 : Female on board berpengaruh negatif terhadap kemungkinan

\section{METODE PENELITIAN}

Teknik Pengumpulan Data

Teknik pengumpulan data yang peneliti gunakan adalah teknik observasi terhadap data sekunder, data sekunder tersebut antara lain Data mengenai aset, kewajiban, jumlah saham beredar, saham kepemilikan manajerial, dan arus kas operasional, pendapatan, biayabiaya operasional, pada perusahaan manufaktur dan terdaftar di Bursa Efek Indonesia.

\section{Obyek Penelitian}

Obyek penelitian dalam penelitian ini adalah perusahaan yang termasuk dalam industri manufaktur dan telah go public serta menerbitkan laporan keuangan tahunan pada periode 2015-2017 yang terdaftar di Bursa Efek Indonesia (BEI) dan idx.co.id. Berdasarkan kriteria tersebut maka perusahaan manufaktur yang terdaftar dalam Bursa Efek Indonesia periode 2015-2017 adalah 143 perusahaan. Alasan pemilihan terjadinya fraudulent financial statement.

perusahaan manufaktur dikarenakan perusahaan manufaktur memiliki rantai proses bisnis yang lebih panjang dibandingkan dengan jenis industri lainnya. Sehingga hal itu berimplikasi pada meningkatnya potensi kecurangan laporan keuangan. Dan juga karena diversity industry dari perusahaan yang cukup luas sehingga diharapkan dapat mendapatkan data dari berbagai macam industri. Industri manufaktur tersebut dapat digolongkan menjadi 18 sektor dan sub sektor bisnis, yaitu pada sektor industri dan dasar kimia terdapat sub sektor semen; sub sektor keramik, porselen, dan kaca; sub sektor logam dan sejenisnya; sub sektor kimia; sub sektor plastik dan kemasan; sub sektor pakan ternak; sub sektor kayu dan pengolahannya; sub sektor pulp dan kertas. Pada sektor aneka industri terdapat sub sektor mesin dan alat berat; sub sektor otomotif dan komponen; tekstil dan garment; alas kali; kabel; elektronika. Pada sektor industri barang konsumsi terdapat sub sektor makanan 
dan minuman; rokok; farmasi; kecurangan dikhususkan kecurangan kosmetik; dan barang keperluan rumah tangga; peralatan rumah tangga. atas laporan keuangan. Terdapat dua kategori yaitu perusahaan yang melakukan kecurangan (fraud) dan Variabel Penelitian perusahaan yang tidak melakukan Variabel Dependen

Variabel dependen atau varibel terikat adalah variabel yang dipengaruhi oleh variabel independen (bebas), disebut juga dengan variabel terikat. Varibel dependen (terikat) yang digunakan dalam penelitian ini yaitu kecurangan yang diproksikan dengan Beneish Mkecurangan (non fraud). Perusahaan dikategorikan melakukan kecurangan apabila memiliki Beneish M-Score >2.2 yakni perusahaan diindikasikan menggunakan variabel dikotomus dengan kategori 1 bagi perusahaan yang diindikasikan melakukan kecurangan dan 0 bagi perusahaan yang tidak diindikasikan melakukan kecurangan. Score. Di dalam penelitian ini

$$
\begin{gathered}
\text { Beneish } M \text {-Score }=-4.84+0.920 \mathrm{DSRI}+0.528 \mathrm{GMI}+0.404 \mathrm{AQI}+0.892 \mathrm{SGI}+ \\
0.115 \mathrm{DEPI}-0.172 \mathrm{SGAI}-0.327 \mathrm{LVGI}+4.679 \mathrm{TATA}
\end{gathered}
$$

Keterangan :

DSRI = Days Sales in Receivable Index

GMI = Gross Margin

$\mathrm{AQI}=$ Asset Quality Index

SGI = Sales Growth Index

DEPI $=$ Depreciation Index

SGAI = Sales and General Administrative Expense Index

LVGI = Leverage Index

TATA = Total Accruals to Total Assets

Variabel Independen

Variabel independen atau variabel bebas adalah variabel yang mempengaruhi variabel dependen (terikat), disebut juga sebagai variabel stimulus dan prediktor.
Variabel yang digunakan dalam penelitian ini, yaitu :

Pressure: Financial Stability

Financial stability merupakan keadaan yang menggambarkan kondisi keuangan 
perusahaan dari kondisi stabil. Aset menggunakan pertumbuhan aset perusahaan dapat digunakan untuk (growth in asset) sebagai proksi melihat kondisi keuangan perusahaan, variabel financial stability (Beneish, karena aset dapat menggambarkan 1997); (Beasley et al., 2000). Financial kekayaan yang dimiliki oleh stability (ACHANGE) dihitung dengan perusahaan. Oleh karena itu peneliti rumus:

$\mathrm{ACHANGE}=\left[\llbracket\right.$ Total Aset $\__{\mathrm{t}}-\llbracket$ Total Aset $\left.{ }_{-}((\mathrm{t}-1))\right] / \llbracket$ Total Aset $\rrbracket \_((\mathrm{t}-1))$

Pressure: External Pressure

External pressure merupakan tekanan yang berlebihan bagi manajemen untuk memenuhi persyaratan daftar bursa, membayar utang atau memenuhi perjanjian utang. Oleh karena itu peneliti menggunakan rasio antara total debt dengan total asset sebagai proksi variabel external pressure. Leverage (LEV) dihitung dengan rumus:

\section{$\mathrm{LEV}=($ Total Debt $) /($ Total Assets $)$}

Pressure: Financial Personal Need

Beasley (1996), COSO (1999), dan Dunn (2004) menunjukkan bahwa ketika eksekutif memiliki kepemilikan saham yang signifikan dalam perusahaan, keuangan perusahaan ikut terpengaruh oleh kondisi keuangan para pengambil keputusan (eksekutif).
Struktur kepemilikan saham ini dapat mempengaruhi tingkat terjadinya kecurangan. Oleh karena itu peneliti menggunakan kepemilikan saham oleh orang dalam sebagai proksi variabel financial personal need. Financial personal need (OSHIP) dihitung dengan menggunakan rumus sebagai berikut:

$$
\text { OSHIP= (Saham Kepemilikan Manajerial }) /(\text { Jumlah Saham Beredar })
$$


Opporunity: Nature of industry

Dalam suatu laporan keuangan terdapat saldo akun yang dinyatakan dengan penilaian subjektif. Hal tersebutlah yang menyebabkan adanya manipulasi laporan keuangan. Saldo dalam akunakun tertentu sebagian besar ditentukan berdasarkan perkiraan dan penilaian subyektif, seperti akun yang tidak dapat ditagih dan obsolete inventory. Oleh karena itu peneliti menggunakan perubahan tingkat piutang sebagai variabel nature of industry (Summers dan Sweeney, 1998). Nature of industry (RECEIVABLE) dihitung dengan rumus:

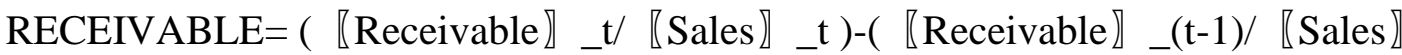 $-(\mathrm{t}-1))$}

\section{Opportunity: Effective Monitoring}

Kecurangan dapat diminimalkan salah satunya dengan mekanisme pengawasan yang baik. Komite audit merupakan suatu komponen yang memiliki peranan yang sangat vital sebagai sistem pengendalian perusahaan. Effective monitoring (IND) dihitung dengan rumus:

$\mathrm{IND}=\%$ anggota independen dalam komite audit

\section{Rationalization}

Independensi auditor eksternal adalah alat pemantauan penting untuk menjamin kualitas pelaporan keuangan. Hubungan manajemen-auditor sangat penting dalam menentukan rasionalisasi di perusahaan. Insiden kegagalan audit dan litigasi meningkat setelah perubahan auditor (Stice, 1991); (St. Pierre dan Anderson, 1984); (Loebbecke et al., 1989). Oleh karena itu, perubahan KAP (AUDCHANGE) digunakan sebagai proksi rationalization.

Capability

Wolfe dan Hermanson (2004) mengemukakan bahwa perubahan direksi akan dapat menyebabkan stress period yang berdampak pada semakin terbukanya peluang untuk melakukan fraud. Penelitian ini memproksikan capability dengan pergantian direksi perusahaan (DCHANGE) yang diukur dengan variabel dummy. 
Dewan Komisaris Independen

Perbedaan kepentingan antara pemilik perusahaan dan manajemen dapat diselaraskan dengan mekanisme tata kelola perusahaan. Pemantauan yang dilakukan oleh dewan komisaris dan pemegang saham merupakan mekanisme penting dalam menyelaraskan kepentingan pemegang saham dan manajemen. Dewan komisaris independen dihitung dengan rumus:

INDCOM = (Jumlah anggota komisaris independen $) /($ Jumlah seluruh anggota dewan komisaris)

\section{Female on Board}

Satu bentuk keragaman berasal dari gaya kepemimpinan wanita yang berbeda. Teori peran sosial kepemimpinan Eagly dan Johnson (1990) dan Eagly et al., (1995) menguraikan bahwa pemimpin perempuan cenderung lebih menunjukkan kepedulian terhadap orang dan mencari kesejahteraan (persekutuan), sementara pemimpin laki-laki cenderung lebih memiliki sifat (agen) yang memperkuat persaingan dan hierarki. Serupa dengan itu, sering dilaporkan dalam praktik bahwa perempuan adalah pendengar yang lebih baik dan mencari pendengar yang lebih baik, terutama dalam kaitannya dengan masalah keuangan. Female on Board dihitung dengan rumus

\section{$F o B=\%$ Female directors on board}

\section{HASIL DAN ANALISIS}

Analisis Deskriptif

Tabel 1. Statistik Deskriptif

\begin{tabular}{llllll} 
& $\mathrm{N}$ & Minimum & Maximum & Mean & $\begin{array}{l}\text { Std. } \\
\text { Deviation }\end{array}$ \\
\hline ACHANGE & 138 & -0.148 & 1.031 & 0.12136 & 0.18418 \\
LEV & 138 & 0.001 & 0.415 & 0.09754 & 0.08591 \\
OSHIP & 138 & 0.000 & 0.573 & 0.04799 & 0.09939 \\
RECEIVABLE & 138 & -0.085 & 0.101 & 0.00437 & 0.02953 \\
IND & 138 & 0.750 & 1.000 & 0.99457 & 0.03659 \\
INDCOM & 138 & 0.200 & 0.600 & 0.38464 & 0.08283 \\
FOB & 138 & 0.000 & 0.670 & 0.11746 & 0.16061 \\
\hline
\end{tabular}


Berdasarkan hasil uji statistik deskriptif yang diperoleh dari 138 data observasi yang terdapat pada Tabel 1. Hasil analisis dengan menggunakan statistik deskriptif terhadap financial stability (ACHANGE) menunjukkan nilai minimum sebesar -0.148 yang dimiliki oleh PT Indocement Tunggal Prakasa Tbk. (INTP) pada tahun 2017, dan nilai maksimum sebesar 1.031 yang dimiliki oleh PT Tunas Alfin Tbk. (TALF) pada tahun 2016 dengan rata-rata sebesar 0.12136. Variabel external pressure (LEV) menunjukkan nilai minimum sebesar 0.001 yang dimiliki oleh PT Lionmesh Prima Tbk. (LMSH) pada tahun 2016, dan nilai maksimum sebesar 0.415 yang dimiliki oleh PT Nippon Indosari Corporindo Tbk. (ROTI) pada tahun 2015 dengan ratarata sebesar 0.09754. Variabel financial personal need (OSHIP) memiliki nilai minimum sebesar 0.000 yang dimiliki oleh beberapa perusahaan seperti PT Indocement Tunggal Prakasa Tbk. (INTP), PT Jembo Cable Company Tbk. (JECC), PT Arwana Citra Mulia Tbk. (ARNA), dan lain-lain yang mana tidak ada kepemilikan saham oleh orang dalam, dan nilai maksimum sebesar 0.573 yang dimiliki oleh PT Indo Acidatama Tbk., (SRSN) pada tahun
2017 dengan rata-rata sebesar 0.04799 . Variabel nature of industry (RECEIVABLE) menunjukkan nilai minimum sebesar -0.085 yang dimiliki oleh PT Pelangi Indah Canindo Tbk. (PICO) pada tahun 2017, dan nilai maksimum sebesar 0.101 yang dimiliki oleh PT Indal Aluminium Industry Tbk. (INAI) pada tahun 2016 dengan ratarata sebesar 0.0037. Variabel ineffective monitoring (IND) menunjukkan nilai minimum sebesar 0.75 yang dimiliki oleh PT Astra Internasional Tbk. (ASII) pada tahun 2015,2016, dan 2017, dan nilai maksimum 1 yang dimiliki oleh semua perusahaan dalam sampel kecuali PT Arwana Citra Mulia Tbk. (ARNA) dan PT Astra Internasional Tbk. (ASII) dengan rata-rata 0.99457. Variabel dewan komisaris independen (INDCOM) menunjukkan nilai minimum sebesar 0.200 yang dimiliki oleh PT Nippres Tbk. (NIPS) pada tahun 2017 dan PT Kimia Farma Tbk. (KAEF) pada tahun 2016 dan 2017 , dan nilai maksimum sebesar 0.600 yang dimiliki oleh PT Tempo Scan Pacific Tbk. (TSPC) pada tahun 2017 dengan rata-rata 0.38464 . Variabel female on board (FOB) menunjukkan nilai minimum sebesar 0 yang dimiliki oleh PT Indocement Tunggal Prakasa Tbk. 
(INTP), PT Delta Djakarta Tbk. Kabelindo Murni Tbk. (KBLM) pada (DLTA), dan lain-lain, dan nilai tahun 2017 sebesar 0.670 dengan ratamaksimum yang dimiliki oleh PT rata sebesar 0.11746 .

Tabel 2. Tabel Statistik

\begin{tabular}{|c|c|c|c|c|}
\hline & & \multicolumn{3}{|c|}{ FRAUD AUDCHANGE DCHANGE } \\
\hline \multirow{2}{*}{$\mathrm{N}$} & Valid & 138 & 138 & 138 \\
\hline & Missing & 0 & 0 & 0 \\
\hline \multicolumn{2}{|c|}{ Mode } & .000 & .000 & .000 \\
\hline \multicolumn{2}{|c|}{ Minimum } & .000 & .000 & .000 \\
\hline \multicolumn{2}{|c|}{ Maximum } & 1.000 & 1.000 & 1.000 \\
\hline
\end{tabular}

Berdasarkan hasil uji statistik yang diperoleh dari 138 data observasi yang terdapat pada tabel 2. Variabel FRAUD memiliki nilai minimum 0 , nilai maksimum 1, dan modus 0. Menunjukkan bahwa dalam penelitian ini lebih banyak perusahaan yang tidak melakukan fraud dibandingkan dengan perusahaan yang melakukan fraud. Variabel AUDCHANGE memiliki nilai minimum 0 , nilai maksimum 1 , dan modus 0. Menunjukkan bahwa dalam penelitian ini lebih banyak perusahaan yang tidak melakukan perubahan KAP secara voluntary selama periode penelitian. Variabel DCHANGE memiliki nilai minimum 0 , nilai maksimum 1, dan modus 0 . Menunjukkan bahwa lebih banyak perusahaan yang tidak melakukan perubahan direktur dibandingkan dengan perusahaan yang melakukan perubahan direktur.

\section{Tabel 3. Frekuensi Fraud}

\begin{tabular}{llllll}
\hline & & Frequency & Percent & \multicolumn{2}{c}{ Valid Percent Cumulative } \\
& & & & Percent \\
\hline \multirow{2}{*}{ Valid } & Non Fraud & 100 & 72.5 & 72.5 & 72.5 \\
& Fraud & 38 & 27.5 & 27.5 & 100.0 \\
& Total & 138 & 100.0 & 100.0 & \\
\hline
\end{tabular}


Dari tabel 3 terdapat 100 perusahaan yang tergolong non-fraud dengan persentase $72.5 \%$ dan 38 perusahaan yang tergolong fraud dengan persentase $27.5 \%$.

Tabel 4. Frekuensi Perubahan KAP

\begin{tabular}{clllll} 
& & \multicolumn{2}{c}{ Frequency } & Percent & \multicolumn{2}{c}{ Valid Percent Cumulative } \\
& & & & Percent \\
\hline \multirow{3}{*}{ Valid } & No Change & 129 & 93.5 & 93.5 & 93.5 \\
\cline { 2 - 5 } & Change in KAP9 & 6.5 & 6.5 & 100.0 \\
Total & 138 & 100.0 & 100.0 & \\
\hline
\end{tabular}

Dari tabel 4 terdapat 129 perusahaan yang tidak melakukan perubahan kantor akuntan publik (KAP) selama periode penelitian dengan persentase $93.5 \%$. Dan hanya 9 perusahaan yang melakukan perubahan kantor akuntan publik (KAP) secara voluntary selama periode penelitian dengan persentase $6.5 \%$.

\section{Tabel 5. Frekuensi Perubahan Direksi}

\begin{tabular}{llllll} 
& & Frequency & Percent & \multicolumn{2}{c}{ Valid Percent Cumulative } \\
& & & & Percent \\
\hline \multirow{2}{*}{$\begin{array}{lllll}\text { Valid } \\
\text { No Change }\end{array}$} & 115 & 83.3 & 83.3 & 83.3 \\
Change in Director & 23 & 16.7 & 16.7 & 100.0 \\
Total & 138 & 100.0 & 100.0 & \\
\hline
\end{tabular}

Dari tabel 5 terdapat 115 perusahaan yang tidak melakukan perubahan direktur dengan persentase $83.3 \%$. Dan

Uji Keseluruhan Model (Overall Model Fit) hanya 23 perusahaan yang melakukan perubahan direktur dengan persentase $16.7 \%$.

Tabel 6 Menilai Keseluruhan Model

\begin{tabular}{ll}
\hline -2LL & Nilai \\
\hline 1. Awal (Blok 0) & 162.564 \\
2. Akhir (Blok 1) & 101.680 \\
\hline
\end{tabular}


Tabel 6 membandingkan nilai 2LogLikelihood (-2LL) pada awal (Block Number $=0)$ dengan nilai 2LogLikelihood (-2LL) pada akhir (Block Number $=1)$. Nilai $(-2 \mathrm{LL})$ awal adalah 162.564. Setelah dimasukkan kesembilan variabel independen, maka nilai (-2LL) akhir mengalami penurunan menjadi sebesar 101.680. Penurunan nilai (-2LL) ini berarti hipotesis nol ditolak. Berarti, penambahan variabel independen ke dalam model fit dan menunjukkan model regresi yang lebih baik sehingga model regresi layak untuk pengujian selanjutnya.

\section{Uji Kesesuaian Koefisien}

Tabel 7. Kesesuaian Koefisien

\begin{tabular}{llll} 
Step & Chi-square & df & Sig. \\
\hline 1 & 12.342 & 8 & .137 \\
\hline
\end{tabular}

Tabel 7 menunjukkan nilai statistik yang nyata antara klasifikasi yang Hosmer and Lemeshow memiliki nilai diprediksi dengan klasifikasi yang signifikansi sebesar $0.137>0.05(\alpha)$ diamati sehingga mampu memprediksi Maka terima Ho, berarti model regresi nilai observasinya atau dapat dikatakan logistik layak dipakai untuk analisis model dapat diterima karena sesuai selanjutnya, karena tidak ada perbedaan dengan data observasinya.

\section{Nagelkerke's R Square}

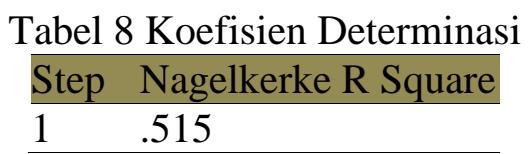

Tabel 8 menunjukkan nilai sebesar $51.5 \%$ sedangkan sisanya Nagelkerke's $R$ Square sebesar $0.515 \quad$ sebesar $48.5 \%$ dijelaskan oleh variabelyang berarti variabel dependen dapat variabel lain diluar model penelitian. dijelaskan oleh variabel independen 
Tabel Klasifikasi $2 \times 2$

Tabel 9. Matriks Klasifikasi

\begin{tabular}{|c|c|c|c|c|}
\hline & \multirow[t]{3}{*}{ Observed } & \multicolumn{3}{|l|}{ Predicted } \\
\hline & & FRAUD & & Percentage \\
\hline & & Non Fraud & Fraud & Correct \\
\hline \multirow{3}{*}{ Step 1} & Non Fraud & 96 & 4 & 96.0 \\
\hline & FRAUD & 16 & 22 & 57.9 \\
\hline & ll Percentage & & & 85.5 \\
\hline
\end{tabular}

$\begin{array}{llll}\begin{array}{l}\text { Matriks klasifikasi menunjukkan } \\ \text { kekuatan prediksi dari model regresi }\end{array} & \text { perusahaan yang diprediksi melakukan } \\ \text { untuk memprediksi kemungkinan } & \text { perusahaan yang tidak melakukan fraud } \\ \text { perusahaan manufaktur yang akan } & \text { (non fraud) adalah sebesar 96\% yang } \\ \text { melakukan kecurangan laporan } & \text { berarti bahwa dengan model regresi } \\ \text { keuangan. Dapat dilihat dari tabel 9, } & \text { yang digunakan terdapat sebanyak 96 } \\ \text { kekuatan prediksi dari model regresi } & \text { perusahaan yang diprediksi akan } \\ \text { untuk memprediksi fraud adalah } & \text { mendapatkan perusahaan yang tidak } \\ \text { sebesar 57.9\%. Hal ini menunjukkan } & \text { melakukan fraud dari total } 100 \\ \text { bahwa dengan model regresi yang } & \text { perusahaan yang diprediksi tidak } \\ \text { digunakan, terdapat sebanyak 22 } & \text { melakukan fraud. Dapat disimpulkan } \\ \text { perusahaan yang diprediksikan akan } & \text { bahwa kekuatan prediksi dari model } \\ \text { melakukan fraud dari total } 38 & \text { regresi sebesar } 85.5 \% .\end{array}$

\section{Uji Model Logistik Secara Parsial (Uji Wald)}

Tabel 10. Koefisien Regresi Logistik

\begin{tabular}{lll} 
Variable & B & Sig \\
\hline ACHANGE & 7.788 & .00050 \\
LEV & .275 & .46500 \\
OSHIP & 1.383 & .34300 \\
RECEIVABLE & 36.662 & .00012 \\
IND & -2.627 & .31050 \\
AUDCHANGE & 4.368 & .00050 \\
DCHANGE & 1.201 & .04350 \\
INDCOM & 3.974 & .11850 \\
FOB & -3.562 & .04300 \\
\hline
\end{tabular}




\section{Pembahasan}

Financial stability (ACHANGE) berpengaruh positif terhadap kemungkinan terjadinya fraudulent financial statement. Hasil penelitian ini didukung oleh penelitian Annisya dkk., (2016) dan Husmawati et al., (2017). Berarti semakin tinggi perubahan aset pada suatu perusahaan, maka semakin tinggi kemungkinan manajemen memanipulasi laporan keuangan. Tingkat pertumbuhan aset perusahaan yang tinggi juga tidak selamanya baik. Pertumbuhan aset yang terlalu tinggi akan memunculkan kekhawatiran tersendiri bagi manajemen jika pada periode selanjutnya pertumbuhan aset tersebut tidaklah sebaik periode sekarang atau bahkan mengalami penurunan cukup drastis. External pressure (LEV) tidak terbukti berpengaruh terhadap kemungkinan terjadinya fraudulent financial statement. Hasil penelitian ini didukung oleh penelitian Martyanta (2013). Hal ini dikarenakan besaran hutang yang terdapat pada suatu perusahaan tidak lagi menjadi faktor utama yang dilihat oleh investor dan kreditor selama utang tersebut digunakan secara produktif, melainkan ada faktor lain yang diperhatikan oleh mereka, seperti adanya tingkat kepercayaan atau jalinan hubungan yang baik antara perusahaan dengan kreditor. Personal financial need (OSHIP) tidak terbukti berpengaruh terhadap kemungkinan terjadinya fraudulent financial statement. Hasil penelitian ini didukung oleh penelitian Martyanta (2013) dan Harto (2016). Hal ini terjadi mungkin karena ada pemisahan yang jelas antara pemilik dan pengelola, sehingga manajemen tidak memiliki kemampuan yang cukup untuk melakukan kecurangan. Selain itu juga mungkin karena perusahaan itu merupakan perusahaan keluarga, yang mana pemilik dan pengelolanya adalah keluarga besar perusahaan tersebut, sehingga tidak ada untung untuk melakukan kecurangan dalam perusahaan sendiri. Nature of industry (RECEIVABLE) berpengaruh positif terhadap kemungkinan terjadinya fraudulent financial statement. Hasil penelitian ini di dukung oleh penelitian Putriasih dkk., (2016) dan Prayatna dan Fitriany (2014). Hal ini terjadi karena akun receivable dapat digunakan sebagai alat untuk memanipulasi laporan keuangan, karena akun ini dapat ditentukan secara subjektif yaitu akun yang tidak dapat ditagih yang 
disebabkan oleh tidak adanya aturan yang pasti mengenai berapa jumlah atau persentase dari piutang yang dijurnal sebagai piutang yang tidak dapat ditagih. Effective monitoring tidak terbukti berpengaruh terhadap kemungkinan terjadinya fraudulent financial statement. Hasil penelitian ini didukung oleh penelitian Husmawati et al., (2017) dan Indarto dan Ghozali (2016). Hal ini dikarenakan ada Peraturan Otoritas Jasa Keuangan Nomor 55/POJK.04/2015 tentang Pembentukan dan Pedoman Pelaksanaan Kerja Komite Audit, pasal 4 yang menyatakan bahwa: "komite audit paling sedikit terdiri dari 3 (tiga) orang anggota yang berasal dari Komisaris Independen dan Pihak dari luar Emiten atau Perusahaan Publik."

\section{Rationalization}

(AUDCHANGE) berpengaruh positif terhadap kemungkinan terjadinya fraudulent financial statement. Hasil penelitian ini didukung oleh penelitian Siddiq dkk., (2017). Pergantian KAP secara voluntary dapat berperan sebagai upaya untuk menghilangkan jejak kecurangan yang terdeteksi oleh auditor/KAP sebelumnya. Capability (DCHANGE) berpengaruh positif terhadap kemungkinan terjadinya fraudulent financial statement. Penelitian ini didukung oleh penelitian Putriasih dkk., (2016) dan Pamungkas et al., (2018). Berarti pada saat perubahan direksi akan menimbulkan stres period dan mengakibatkan terbukanya peluang untuk melakukan kecurangan. Karena belum memahami situasi atau sistem perusahaan sehingga direksi lain, manajer atau bawahannya dapat melakukan tindakan kecurangan juga.

Dewan komisaris independen (COMIND) tidak terbukti berpengaruh terhadap kemungkinan terjadinya fraudulent financial statement. Variabel dewan komisaris independen memiliki arah yang searah dengan fraudulent financial statement. Ini berarti komisaris independen dalam penelitian ini tidak efektif, yaitu tidak melakukan tugasnya dengan baik. Female on board (FOB) berpengaruh negatif terhadap kemungkinan terjadinya fraudulent financial statement. Hasil penelitian ini didukung oleh penelitian Capezio dan Mavisakalyan (2016) dan Ghafoor et $a l .$, (2018). Hal ini dapat terjadi karena gaya kepemimpinan perempuan yang berbeda dengan laki-laki. Perempuan cenderung lebih berhati-hati, teliti, peka akan kecurangan, perhatian, memakai 
perasaan dan hati dibandingkan dengan

laki-laki yang cenderung lebih agresif.

\section{KESIMPULAN}

Berdasarkan hasil dan analisis yang telah dilakukan dalam penelitian, maka kesimpulan dari hasil penelitian ini adalah financial stability, nature of industry, rationalization, capability berpengaruh positif terhadap kemungkinan terjadinya fraudulent financial statement. Female on board berpengaruh negatif terhadap kemungkinan terjadinya fraudulent financial statement. External pressure, personal financial need, dewan komisaris tidak berpengaruh terhadap kemungkinan terjadinya fraudulent financial statement. Berdasarkan hasil analisis dan kesimpulan yang telah

\section{DAFTAR PUSTAKA}

Abbott, L. J., Park, Y., \& Parker, S. (2000). The Effects of Audit Committee Activity and Independence on Corporate Fraud, Vol.26, No.11.

Abbott, L. J., \& Parker, S. (2000). Auditor selection and audit committee characteristics. Auditing, Vol.19, No.2, p.46-66. diuraikan di atas, maka terdapat beberapa saran yang dapat diberikan oleh peneliti untuk penelitian selanjutnya. Bagi peneliti selanjutnya sebaiknya menggunakan variabelvariabel baru untuk mengetahui faktorfaktor lain yang mempengaruhi fraudulent financial statement, seperti, fraud pentagon atau variabel lainnya agar dapat menjelaskan hubungannya dengan fraudulent financial statement, menggunakan variabel dependen yang lain sebagai pengukur dari fraudulent financial statement, seperti F-Score. Selain itu juga dapat menggunakan proksi lain untuk variabel-variabel independen. Seperti, Gross Profit Margin untuk variabel financial stability.
A. E. (2014). Pengaruh Good Corporate Governance pada Manajemen laba (Studi Empiris pada Perusahaan Manufaktur yang terdaftar di BEI tahun 2013-2014), p.1-14. 
Abdullahi, R. 'u, \& Mansor, N. (2015). Fraud Triangle Theory and Fraud Diamond Theory. Understanding the Convergent and Divergent For Future Research. International Journal of Academic Research in Accounting Finance and Management Sciences, Vol.5, No.4, p.38-45.

Adams, R. B. (2016). Women on boards: The superheroes of tomorrow? Leadership Quarterly, Vol.27, No.3.

Annisya, M., Lindrianasari, \&

Asmaranti, Y. (2016).

Pendeteksian Kecurang

Laporan Keuangan

Menggunakan Fraud Diamond.

Jurnal Bisnis Dan Ekonomi, Vol.23, No.1, p.72-89.

Arme, D., Harahap, T., \&

Triyanto, D. N. (2017). Pengujian Fraud Diamond dalam Kecurangan Laporan Keuangan (Studi Kasus Pada Perusahaan Pertambangan yang terdaftar di Bursa Efek Indonesia tahun 2011-2015) . EProceeding of Management, Vol.4, No.1, p.420-427.

Association of Certified Fraud Examiners. (2018). Report To The Nations: 2018 Global Study on Occupational Fraud and Abuse.

Azis, H. A. (2017). Ikhtisar Hasil Pemeriksaan Semester II Tahun 2016.

Beasley, M. S. (1996). An Empirical Analysis of the Relation Between the Board of Director
Composition and Financial Statement Fraud.

Beasley, M. S., Carcello, J. V., Hermanson, D. R., \& Lapides, P. D. (2000). Fraudulent financial reporting: Consideration of industry traits and corporate governance mechanisms. Accounting Horizons, Vol.14, No.4, p.441454.

Beneish, M. D. (1997). Detecting

GAAP violation: Implications for assessing earnings management among firms with extreme financial performance. Journal of Accounting and Public Policy, Vol.16, No.3, p.271-309.

Beneish, M. D. (1999). The

Detection of Earnings Manipulation. Financial Analysts Journal, Vol.55, No.5, p.24-36.

Betz, M., Shepard, J. M., \&

O'Connell, L. (1989). Gender Differences in Proclivity for Unethical Behavior.

Byrnes, J. P., Miller, D. C., \& Schafer, W. D. (1999). Gender differences in risk taking: A meta-analysis. Psychological Bulletin, Vol.125, No.3, p.367383.

Capezio, A., \& Mavisakalyan, A.

(2016). Women in the boardroom and fraud: Evidence from Australia. Australian Journal of Management, Vol.41, No.4, p.719-734. 
Cooper, R. ., \& Schindler, P.

(2014). Business research method. New York: McGrawHill.

COSO. (1999). Fraudulent

Financial Reporting: 19871997. Dechow, P. M., Sloan, R. G., \& Sweeney, A. P. (1995). Detecting Earnings Management. The Accounting Review, Vol.70, No.2, p,193225.

Dechow, P. M., Sloan, R. G., \& Sweeny, A. P. (1996). Causes and consequences of earnings manipulations: an analysis of firm subject enforcement action by the SEC. Contemporary Accounting Research, Vol.13, No.1, p.1-32.

Dunn, P. (2004). The Impact of Insider Power on Fraudulent Financial Reporting, Vol.30, No.3, p.397-412.

Eagly, A. H., \& Johnson, B. T. (1990). Gender and Leadership Style: A Meta-Analysis. Psychological Bulletin, Vol.108, No.2, p.233-256.

Eagly, A. H., Karau, S. J., \& Makhijani, M. G. (1995). Gender and the Effectiveness of Leaders: A Meta-Analysis. Psychological Bulletin, Vol.117, No.1, p.125-145.

Eisenhardt, M. (1989). Agency

Theory: and Assessment Review. Academy of Management Review, Vol.14, No.1, p.57-74.

FCGI. (2001). Tata Kelola
Perusahaan. Seri Tata Kelola Perusahaan, Jilid 1.

Ghafoor, A., Zainudin, R., \& Mahdzan, N. S. (2018). Factors Eliciting Corporate Fraud in Emerging Markets: Case of Firms Subject to Enforcement Actions in Malaysia. Journal of Business Ethics, p.1-22.

Ghozali, I. (2016). Aplikasi

Analisis Multivariate dengan Program SPSS 23, Edisi 8. Semarang Badan Penerbit Universitas Diponegoro.

Gul, F. A., Fung, S. Y. K., \& Jaggi, B. (2009). Earnings quality: Some evidence on the role of auditor tenure and auditors' industry expertise. Journal of Accounting and Economics, Vol.47, No.3, p.265-287.

Harto, C. T. \& P. (2016).

Pengujian Teori Fraud
Pentagon Pada Sektor
Keuangan Dan Perbankan Di
Indonesia. Simposium Nasional
Akuntansi, p.1-21.

Husmawati, P., Septriani, Y.,

Rosita, I., \& Handayani, D. (2017). Fraud Pentagon Analysis in Assessing the Likelihood of Fraudulent Financial Statement (Study on Manufacturing Firms Listed in Bursa Efek Indonesia Period 2013-2016). International Conference of Applied Science on Engineering, Business, Linguistics and Information Technology (ICo-ASCNITech), p.13-15. 
Indarto, S. L., \& Ghozali, I.

(2016). Fraud Diamond:

Detection Analysis on the

Fraudulent Financial Reporting.

Risk Governance and Control:

Financial Markets \&

Institutions, Vol.6, No.4.

Ikatan Akuntan Indonesia (2015).

Standar Akuntansi Keuangan

Efektif per 1 Januari 2015

Ikatan Akuntan Indonesia (2017).

Standar Akuntansi Keuangan

Efektif per 1 Januari 2017

Jansen, I. P., Ramnath, S., \&

Yohn, T. L. (2012). A Diagnostic

for Earnings Management Using

Changes in Asset Turnover and

Profit Margin, Vol.29, No.1, p.221-251.

Jensen, C., \& Meckling, H.

(1976). Theory of the Firm: Manajerial Behaviour, Agency Costs and Ownership Structure I, Vol.3, p.305-360.

Kieso, D. E., Weygandt, J. J., \& Warfield, T. D. (2018). Intermediate Accounting, Edisi 3.

KNKG. (2006). Pedoman Umum Good Corporate Governance Indonesia.

KPMG Forensics. (2014). Fraud

Risk Management: Developing a strategy for prevention, detection, and response, May, p.1-57.

Larastomo, J., Perdana, H. D.,

Triatmoko, H., \& Sudaryono, E.

A. (2016). Pengaruh Tata
Kelola Perusahaan dan Penghindaran Pajak Terhadap Manajemen Laba Pada Perusahaan Manufaktur di Indonesia, Vol.6 April, p.63-74.

Loebbecke, J. K., Eining, M. M.,

\& Willingham, J. J. (1989). Auditors' Experience with Material Irregularities:

Frequency, Nature, and Detectability. Auditing: A Journal of Practice \& Theory.

Luthan, E., Satria, I., \& Ilmainir.

(2016). The Effect of Good Corporate Governance Mechanism to Earnings Management before and after IFRS Convergence. Procedia Social and Behavioral Sciences, Vol.219, p.465-471.

Maccarthy, J. (2017). Using

Altman Z-score and Beneish Mscore models to detect financial fraud and corporate failure: A case study of Enron Corporation. International Journal of Finance and Accounting,Vol.6, No.6, p.159166.

Manurung, D. T. H., \& Hardika, A. L. (2015). Analysis of factors that influence financial statement fraud in the perspective fraud diamond: Empirical study on banking companies listed on the Indonesia Stock Exchange year 2012 to 2014. International Conference on Accounting Studies (ICAS), August, p.280286. 
Martyanta, D. (2013). Pendeteksian

Kecurangan Laporan Keuangan Melalui Faktor Risiko Tekanan dan Peluang (Studi Kasus pada Perusahaan yang Mendapat Sanksi dari Bapepam Periode 2002-2006). Diponegoro Journal of Accounting, Vol.2, p.1-12.

No.99, S. (2002). Consideration of Fraud in a Financial Statement Audit. October, p.167-218.

Nugraheni, N. K., \& Triatmoko, H. (2016). Analisis FaktorFaktor yang Mempengaruhi Terjadinya Financial Statement Fraud: Perspektif Diamond Fraud Theory, p.118-143.

Oktarigusta, L. (2017). Terjadinya Financial Statement Fraud Di Perusahaan ( Studi Empiris Pada Perusahaan Manufaktur Yang Terdaftar Di BEI Tahun 2012-2015), Vol.19, No.2.

Otoritas Jasa Keuangan. (2014).

Peraturan Otoritas Jasa

Keuangan Nomor

33/POJK.04/2014 Tentang

Direksi dan Dewan Komisaris

Emiten Atau Perusahaan Publik.

Otoritas Jasa Keuangan. (2015).

Peraturan Otoritas Jasa

Keuangan Nomor

55/POJK.04/2015 Tentang

Pembentukan dan Pedoman

Pelaksanaan Kerja Komite Audit.

Pamungkas, I. D., Ghozali, I., \& Achmad, T. (2018). A pilot study of corporate governance and accounting fraud: The fraud diamond model. Journal of

Business and Retail

Management Research

(JBRMR), Vol.12, No.2, p.253261.

Ph.D, G. P. (2017). Teori

Organisasi, Edisi 4. Penerbit ANDI.

Powell, M., \& Ansic, D. (1997).

Gender differences in risk behaviour in financial decision making, Vol.18.

Prayatna, A. P., \& Fitriany.

(2014). Fraud Triangle

(Pressure, Opportunity, and

Rationalization) and The Level of Accounting Irregularities in Indonesia. National Accounting Conference.

Priantara, D. (2013). Fraud Auditing \& Investigation. Jakarta: Mitra Wancana Media.

Putriasih, K., Herawati, N. N. T.,

\& Wahyuni, M. A. (2016). Analisis Fraud Diamond Dalam Mendeteksi Financial Statement Fraud: Studi Empiris pada Perusahaan Manufaktur yang Terdaftar di Bursa Efek Indonesia (bei) Tahun 20132015. JIMAT (Jurnal Ilmiah Mahasiswa Akuntansi) Undiksha, Vol.6, No.3, p.1-22.

Razali, W. A. A. W. M., \& Arshad, R. (2014). Disclosure of Corporate Governance Structure and the Likelihood of Fraudulent Financial Reporting. Procedia - Social and Behavioral Sciences, Vol.145, p.243-253. 
Ruankaew, T. (2016). Beyond the Fraud Diamond, Vol.7, No.1, p.474-476.

Santoso, P. B. (2015). Keagenan (Agency). Penerbit Ghalia Indonesia.

Schuchter, A., \& Levi, M. (2015).

Beyond the fraud triangle: Swiss and Austrian elite fraudsters. Accounting Forum, Vol.39, No.3, p.176-187.

Scott, W. R. (2015). Financial Accounting Theory, Edisi 7.

Sekaran, U. ; R. B. (2017).

Metode Penelitian Bisnis, Edisi 6. Penerbit Salemba Empat.

Shelton, A. M. (2014). Analysis of Capabilities Attributed to the Fraud Diamond.

Shu, S. Z. (2000). Auditor

Resignations: clientele effects and legal liability. Journal of Accounting \& Economics, Vol.1, No.1, p.173-205.

Siddiq, F. R., Achyani, F., \&

Zulfikar. (2017). Fraud Pentagon dalam Mendeteksi Financial Statement Fraud. Prosiding Seminar Nasional Dan The 4th Call for Syariah Paper, p.1-14.

Skousen, C. J., Smith, K. ., \&

Wright, C. . (2008). Detecting

And Predicting Financial Statement Fraud: The Effectiveness of The Fraud Triangle And SAS No 99.
Soebyakto, B. B., Mukhtaruddin,

Delamat, H., Dewi, K., \& Pratama, A. F. (2018). Female Commissioner and Director, and Earnings Management: Study on Manufacturing Companies Listed on Indonesia Stock Exchange, Vol.22, No.4, p.1-10.

St. Pierre, K., \& Anderson, J.

(1984). An analysis of factors associated with lawsuits against public accountants. The Accounting Review.

Stice, J. D. (1991). Using

Financial and Market Information to Identify PreEngagement Factors Associated with Lawsuits against Auditors. The Accounting Review.

Sugiarto, H., \& Anastasia, N.

(2018). Pengaruh Corporate Governance dan Struktur Kepemilikan Terhadap Earning Management dengan Ukuran Perusahaan Sebagai Variabel Kontrol, Vol.6, No.2.

Summers, S. L., \& Sweeney, J. T. (1998). Fraudulently misstated financial statements and insider trading: An empirical analysis. Accounting Review.

Susilana, R. (2015). Modul 6

Populasi dan Sampel. Modul Praktikum, 9.

Thiagarajan, S. R., \& Lev, B.

(1993). Fundamental Information Analysis, Vol.31, No.2, p.190-215. 
Tiffani, L., \& Marfuah. (2015).

Deteksi Financial Statement Fraud Dengan Analisis Fraud Triangle Pada Perusahaan Manufaktur Yang Terdaftar di Bursa Efek Indonesia. Jaai, Vol.19, No. 2,Desember, p.112125.

Tugas, F. C. (2012). Exploring a

New Element of Fraud: A Study on Selected Financial Accounting Fraud Cases in the World, Vol.2, No.6, p.112-121.

Utomo, L. P. (2018). Kecurangan Dalam Laporan Keuangan " Menguji Teori Fraud Triangle”, Vol.19, No.01, p.77-88.

Weygandt, J. J., Kimmel, P. D., \&

Kieso, D. E. (2015). Financial Accounting: IFRS Edition, Edisi 3. John Wiley \& Sons Inc.

Weygandt, J. J., Kimmel, P. D., \& Kieso, D. E. (2016). Accounting Principles, Edisi 12. New Jersey: John Wiley \& Sons Inc.

Wolfe, D. T., \& Hermanson, D. R. (2004). The Fraud Diamond: Considering the Four Elements of Fraud. CPA Journal, Vol.74, No.12, p.38-42.

Yusof. K, M., Khair A.H., A., \& Simon, J. (2015). The Macrotheme Review, Vol.4, No.3, p.126-145.

Zaki, N. M. (2017). The
Appropriateness of Fraud Triangle and Diamond Models in Assessing the Likelihood of Fraudulent Financial Statements - An Empirical Study on Firms Listed in the Egyptian Stock Exchange. International Journal of Social Science and Economic Research, Vol.02, No.02, p.2403-2433. 